\title{
EFFECT OF STOCK INDICES ON CASH FLOW AND EARNINGS MANAGEMENT
}

\author{
A. Joudaky \\ Graduated from Payam Noor University of Behshahr, and Payam Noor University of Tehran, \\ Iran
}

Published online: 08 August 2017

\begin{abstract}
The main objective of this study is to investigate the effect of stock indices on cash flow and earnings management in companies listed on Tehran Stock Exchange. In other words, this study has tried to answer the question that whether the stock indices on cash flow and earnings management in companies listed on Tehran Stock Exchange can weaken the correlation between free cash flows and earnings management or not? To answer the question, a sample of 104 companies listed on Tehran Stock Exchange during 2011-2015 is studied. The variable of earnings management is evaluated using Jones Model (1995). To test research hypotheses, regression models are used at the confidence level of 95\%. The results obtained from this study show that in general, there is significant correlation between earnings management and free cash flows. Then, the effect of stock indices on cash flow and earnings management on the correlation between free cash flows and earnings management is studied in the companies listed on Tehran Stock Exchange. The results have shown that there is no significant correlation between earnings management and managerial stock ownership in companies with high free cash flow and low growth.
\end{abstract}

Key words: stock indices, free cash flows, stock ownership, earnings management.

Author Correspondence, e-mail: author@cmu.ac.ir

doi: http://dx.doi.org/10.4314/jfas.v9i2s.840

\section{INTRODUCTION}

One of the most important goals in field of financial reporting is providing useful information for investors, creditors and other actual and potential users in relevant decisions of investment and crediting and other decisions. One of the most important criteria applied by the said 
groups to estimate the profitability of company, prediction of future profits and relevant risks and management performance appraisal could be current and past profits of company. Continuity of industrial revolution in $19^{\text {th }}$, establishment of large factories and implementation of big industrial projects needed huge investments. Providing such investments was beyond financial facilities of one or more investors and on one hand, one or more investors had not the ability of taking commercial risk of such big activities.

Hence, in this field, some companies were established, in which the responsibility of owners of capital was limited to the level of their investment and in frame of such cooperation, small equipping capitals could be adequate way to supply huge investments and to distribute commercial risks.

According to the mentioned, capitals of such companies could be divided to stocks and their stocks could be also assigned. Promotion of stock transactions caused prosperity of capital market and cooperation of owners of small capitals in this market. Regulating the manner of management of stock companies and the relations of stockholders through codification of regulations by governments, ordering some transactions of bonds through creating stock exchange have been other factors led to establishment of stock companies and increased investment of investors, which were neither directly participated in management of companies and nor had such tendency. Stock companies are usually managed by a board of directors formed of big investors and their selected members. Continuing the process of evolution in ownership relations and capital management at the developed industrial countries led to advent of a new group of professional and skilled managers, who had sometimes a share in their capital in addition to have absolute authority to manage the economic units. The goal of management is to show the company sustainable in looks of investors and capital market.

\section{RELEVANT THEORY OF EARNINGS MANAGEMENT}

According to the relevant works in field of accounting, there is no consensus on a unit theory to discriminate and predict earnings management. However, review of academic literature of earnings management shows dominance of the theory of firm among competing theories. In this section, the relationship of earnings management theories with value is given and then, the theories are explained and the theory of firm is considered as the best and dominant theory in focus of discussion for 3 reasons as follows:

1) It is older than other theories in field of relevant works 
2) Relevant theories of earnings management are lender of the theory; in other words, the theory is considered as a paradigm for the collection of competing theories

3) Moreover, relevant theories are typically an approach of theory of firm. Then, theory of firm is introduced using 3 approaches including contract cost approach, decision making approach and legal-political approach. In the rest of the discussion, these approaches and relevant earnings management approaches are described independently.

\section{RELEVANT WORKS IN FIELD OF CASH FLOW AND EARNINGS MANAGEMENT}

In a study conducted by Jensen under the title of "Theory of the firm: Managerial behavior, agency costs, and ownership structure" (2013) studied problems with agency of free cash flows and the effect of finance of firms on it for the first time. In this study, Jensen has studied the role of debts and liabilities in stimulation of organizational efficiency. Jensen has predicted that when managers have more free cash flows, they show opportunistic behaviors such as investment in projects with lower net cash flows, effort to make income, taking additional costs and waste of revenue and similar behaviors. For example, purchase of assets without earning production, creating extremist job opportunities and excessive use of assets could cause waste of firm's revenue. Jensen has predicted that increased leverage can make managers disciplined and could decline their opportunistic behaviors. This is because; debt settlement could leave less additional cash flows available for the managers.

In the study conducted by Gul and Tsui, the relationship between free cash flows, debt supervising role and audit fee is studied. Gul et al have found in this study that there is positive correlation between free cash flows and audit fees in firms with low level. Moreover, they found that the interaction between free cash flows and management capital ownership in high and low level firms is respectively in low and high level.

Jonsen and Sharma have conducted a study under the title of "relationship between earnings management and free cash flow in Australia and in firms with low and high growth" and found that in firms with low growth, there is direct and significant correlation between accruals and free cash flows. This is because; in these companies, managers try to improve weak performance of business unit through accruals. However, no significant correlation was found in companies with high growth. 
Jacob (2014) has conducted a study under the title of "policy of dividend payment, financial flexibility and agency costs of free cash flows". In this study, the policy of payment of dividend is considered under the title of a corporate governance mechanism and it has been found that dividend, agency costs and free cash flows could be restricted through distribution of available cash flows.

\section{ANALYTICAL AND CONCEPTUAL MODEL OF RESEARCH}

In this study, conceptual and analytical model is a cross-sectional model created using regression model of firm (i) and time (t). According to the investigations, adjusted model of Jones is the strongest model to describe and predict earnings management. Accordingly, in this study, the said model is used to estimate accruals. In Jones' adjusted model, at the first, the accruals are calculated as follows:

$$
T A_{t, i}=\Delta C A_{t, j}-\Delta C L_{t, t}-\Delta C A S H_{t, i}+\Delta S T D_{t, t}-D E P_{t, t}
$$

TA: total accruals of firm $\mathrm{i}$ in year $\mathrm{t}$

$\mathrm{CA}_{\mathrm{t}, \mathrm{i}}$ : change in current asset of firm $\mathrm{i}$ between year $\mathrm{t}$ and $\mathrm{t}-1$

$\mathrm{CL}_{\mathrm{t}, \mathrm{i}}$ : change in current debt of firm $\mathrm{i}$ between year $\mathrm{t}$ and $\mathrm{t}-1$

$\mathrm{CASH}_{\mathrm{t}, \mathrm{i}}$ : change in cash flow of firm o between year $\mathrm{t}$ and $\mathrm{t}-1$

$\mathrm{STD}_{\mathrm{t}, \mathrm{i}}$ : change in current portion of long-term debt of firm $\mathrm{i}$ between year $\mathrm{t}$ and $\mathrm{t}-1$

$\mathrm{DEP}_{\mathrm{t}, \mathrm{i}}$ : depreciation cost of firm $\mathrm{i}$ in year $\mathrm{t}$

After analysis of accruals, parameters $\alpha 1, \alpha 2$ and $\alpha 3$ are estimated to determine accruals as follows:

$$
T A_{i, t} / A_{i, t-1}=\alpha_{1}\left(1 / A_{i, t-1}\right)+\alpha_{2}\left(\Delta R E V_{i s} / A_{i t s-1}\right)+\alpha_{3}\left(P P E_{i t} / A_{i t s-1}\right)+\varepsilon_{i t}
$$

Where;

$\mathrm{TA}_{\mathrm{i}, \mathrm{t}}$ : total accruals of firm $\mathrm{i}$ in year $\mathrm{t}$

$\mathrm{REC}_{\mathrm{t}, \mathrm{i}}$ : change in earnings per sale of firm $\mathrm{i}$ between year $\mathrm{t}$ and $\mathrm{t}-1$

$\mathrm{PPE}_{\mathrm{t}, \mathrm{i}}$ : gross property, machinery and equipment of firm $\mathrm{i}$ in year $\mathrm{t}$

$\mathrm{t}, \mathrm{i}-1$ : total book value of assets of firm $\mathrm{i}$ in year $\mathrm{t}-1$

$\epsilon_{i t}$ : Uncertain effects of random factors

$\alpha_{1}, \alpha_{2}, \alpha_{3}$ : Estimated parameters of firm

After analysis of parameters $\alpha 1, \alpha 2$ and $\alpha 3$ through least square method according to the following formula, the accruals are determined as follows: 


$$
\left.\mathrm{NDA}_{i, j}=\alpha_{1}\left(1 / \mathrm{A}_{\mathrm{i},-1}\right)+\alpha_{2}\left[\Delta \mathrm{REV}_{\mathrm{i}, \mathrm{t}}-\Delta \mathrm{REC}\right) / \mathrm{A}_{\mathrm{i}, \mathrm{l}-1}\right]+\alpha_{3}\left(\mathrm{PPE}_{\mathrm{i}, \mathrm{l}} / \mathrm{A}_{\mathrm{i}, \mathrm{l}-1}\right)
$$

Where;

$\mathrm{NDA}_{\mathrm{i}, \mathrm{t}}$ : non-discretionary accruals of firm $\mathrm{i}$ in year $\mathrm{t}$

$\mathrm{REV}_{\mathrm{i}, \mathrm{t}}$ : change in revenue per sale of firm $\mathrm{i}$ between year $\mathrm{t}$ and $\mathrm{t}-1$

REC: change in receivables of firm $i$ between year $t$ and $t-1$

$\mathrm{PPE}_{\mathrm{i}, \mathrm{t}}$ : gross property, machinery and equipment of firm $\mathrm{i}$ in year $\mathrm{t}$

$A_{i t-1}$ : total book value of assets of firm $i$ in year $t-1$

Finally, discretionary accruals (DA) are estimated after determination of NDA as follows:

$$
\mathrm{DA}_{\mathrm{i}, \mathrm{t}}=\left(\mathrm{TA}_{\mathrm{i}, \mathrm{t}} / \mathrm{A}_{\mathrm{i}, \mathrm{t}-\mathrm{l}}\right)-\mathrm{NDA}_{\mathrm{i}, \mathrm{t}}
$$

\section{ANALYSIS OF FREE CASH FLOWS}

In this study, Len and Plessen model is used to determine free cash flows of business unit. According to this model, free cash flows are calculated using following formula:

$$
F C F_{t, t}=\left(I N C_{i, t}-T A X_{t, t}-I N T E P_{t, t}-P S D I V_{t, t}-C S D I V_{t, t}\right] / A_{t, t-1}
$$

Where;

$\mathrm{FCF}_{\mathrm{i}, \mathrm{t}}$ : free cash flows of firm in year $\mathrm{t}$

$\mathrm{INC}_{\mathrm{i}, \mathrm{t}}$ : operating profit before precipitation of firm in year $\mathrm{t}$

$\mathrm{TAX}_{\mathrm{i}, \mathrm{t}}$ : total tax paid by firm in year $\mathrm{t}$

INTEP $_{\mathrm{i}, \mathrm{t}}$ : payment of firm in year $\mathrm{t}$

$\operatorname{IPSDIV}_{\mathrm{i}, \mathrm{t}}$ : Profit of privileged shareholders paid by firm in year $\mathrm{t}$

CSDIV $_{\mathrm{i}, \mathrm{t}}$ : Profit of ordinary shareholders paid by firm in year $\mathrm{t}$

$A_{i . t-1}$ : Total book value of firm assets in year $\mathrm{t}-1$

According to the studies of Kalapour and Trumili, total market value of equity and total book value to total debts ratio to book value of total assets has higher correlation coefficient with growth of business unit compared to other criteria.

\section{ANALYSIS OF MANAGERIAL STOCK OWNERSHIP VARIABLE}

Ownership of managerial stock indices is measured in form of ordinary share by the executive board of directors and non-executive board of directors and the information are indirectly extracted from disclosure of annual financial statements. 


\section{$\mathrm{MSO}=\frac{\text { OSO }+\mathrm{DSO}}{\text { TOTSHRS }}$}

Where;

OSO: number of ordinary share owned by executive board

DSO: number of share owned by non-executive board

TOTSHRS: total ordinary share for stockholders

For purpose of analysis of the positive effect of managerial ownership variable in some studies, following methods are used: number of ordinary share of company available for executive and non-executive board of directors to show the ownership of managerial share.

a) After estimating the above mentioned percentage, the ownership percentage of managerial share of companies is arranged in upward form and then, the first and fourth quarters are determined for them. To this end, the company with managerial stock ownership in fourth quarter has high managerial stock ownership percentage and the company with managerial stock ownership in first quarter has low managerial stock ownership. Therefore, managerial stock ownership is a virtual variable (0 and 1) and in regression model, it is equal to 1 for the company with high managerial stock ownership and is 0 for the company with low managerial stock ownership.

b) After performing the first method, to perform the second method, declaration No.18 [218APB] is used. According to this declaration, direct or indirect investment in at least $20 \%$ of stock with the right to vote in a unit of investment leads to influence in investment unit; unless otherwise is noted.

Hence, according to the declaration, it could be found that if managerial stock ownership or other stockholders own more than $20 \%$ of stock with right to vote of a company, their influence in companies could be an effective influence and it is assumed that the stockholders have required capability to affect decisions and policies of Investment Company.

Hence, if the managerial stock of a company of a company is higher than $20 \%$, the MSO variable gets 1 ; otherwise, 0 is given. In this regard, the managerial stock percentage higher than $20 \%$ means efficient effectiveness and the stock percentage lower than $20 \%$ means lack of efficient effectiveness on financial decisions and policies.

\section{ANALYSIS OF CONTROL VARIABLES}

Short-term and long-term debt interest costs 
According to the mentioned, debt contracts could affect earnings management. Sweeney have observed considerable manipulations in companies neglecting provisions of debt contracts. To control this effect, logarithm of short-term and long-term debt interest cost is entered to regression model as a control variable, since change in interest cost could be resulted from change in financial leverage.

\section{Firm size}

According to the findings of Moses, Michelson et al and Zeme Zuskii et al, in larger firms, the motivation of managers to manipulate earnings is more than other firms and in smaller firms, the motivation of managers to apply earnings management is less than others. In other words, there is significant and direct correlation between firm size and earnings management. On the contrary, some scholars believe that the larger the firm size is, the less earnings management would be; because such firm is exposed to careful handling more than others.

Hence, in this study, logarithm of total book value of firm asset is used as a criterion to determine firm size in regression model as control variable.

In this study, to estimate growth variable and to separate the companies to low and high growth, market value of corporate stock at the end of fiscal year is used.

\section{ANALYSIS OF SEPARATION OF FREE CASH FLOWS AND COMPANY'S GROWTH}

According to the studies of Adabshen and Chang et al and according to the dominant conditions of companies listed on Tehran Stock Exchange, to determine statistical population in this study, median is used to separate free cash flows and company's growth. In this field, if free cash flow of a company is higher than median of free cash flows of sample companies, the company has high free cash flow; otherwise, it has low cash flow. Moreover, if growth of a company is more than median growth of sample companies, the company has high growth; otherwise, it has low growth.

\section{Testing hypotheses}

In this study, the desired methods for data analysis and testing hypotheses are considered as follows: 
1- To estimate parameters $\alpha_{1}, \alpha_{2}, \alpha_{3}$ to determine discretionary accruals based on Jones' adjusted model, Excel and SPSS software programs are used.

2- To analyze 4 hypotheses of the study, multivariate linear regression is used and to test significance of correlation between variables, p-value (sig) test is used based on accumulative data. Regression model is used to test the research hypotheses as follows:

$$
\begin{aligned}
& D A_{t, t}=\beta_{0}+\beta_{1} F C F_{t, t}+\beta_{2} \mathrm{MSO}_{t, t}+\beta_{4} F C F_{t, t} \times \mathrm{MSO}_{t, t}^{+}+ \\
& \beta_{6} \text { SIZE }+\beta_{7} \text { INTEXP }
\end{aligned}
$$

Where;

$D A_{i, t}:$ discretionary accruals of firm in year $\mathrm{t}$

$F C F_{i . t}$ : free cash flows of firm in year $\mathrm{t}$

$M S O_{i . t}$ : Managerial stock ownership owned ordinarily by executive board and non-executive board

$S I Z E_{i, t}:$ Logarithm of book value of total assets of firm in year $\mathrm{t}$

INTEXP $P_{i . t}$ : Logarithm of total short-term and long-term debt interest cost of firm in year $\mathrm{t}$ $S I Z E_{i, t}:$ Logarithm of book value of total assets in year $\mathrm{t}$

The target population in this study consists of all companies listed on Tehran Stock Exchange from 2011 to 2015.

Hence, in this study, the main objective is studying 450 companies listed on Tehran Stock Exchange. To this end, 104 qualified companies were selected as statistical sample. As each company has 5 sets of financial data in financial statements from 2011 to 2015, the total number of company-year observations is equal to 520 cases.

According to the mentioned (introduction, literature and objectives), the research hypotheses are codified as follows:

- Main hypothesis 1: there is significant correlation between discretionary accruals and free cash flow index.

- Secondary Hypothesis 1: in the companies with low growth, there is significant correlation between discretionary accruals and free cash flow. 
- Main Hypothesis 2: there is significant correlation between discretionary accruals and managerial stock.

- Secondary Hypothesis 2: in companies with free cash flows with low growth, there is significant correlation between discretionary accruals and managerial stock.

\section{Data analysis}

According to table 1, central sub-indices such as mean value and median and distribution indices such as standard deviation, kurtosis and skewness are estimated for different variables. High mean value from the median shows large points in the data. This is because; mean value is affected by these values. In these cases of data distribution, the skew is rightward; otherwise, skewness is leftward and in some variables, mean value and median are close to each other and the data distribution in these cases is symmetric.

Table 1: Descriptive indices of variables under central indices, distribution indices and statistics distribution

\begin{tabular}{|c|c|c|c|c|c|c|c|}
\hline $\begin{array}{c}\text { Variables } \\
\text { Indices }\end{array}$ & DA & FCF & MSO & FCF*MS & Growth & INTEXP & SIZE \\
\hline Number & 520 & 520 & 520 & 520 & 520 & 520 & 520 \\
\hline Mean & 0.048171 & 0.080116 & 0.654268 & 0.053834 & 1.573179 & 4.250101 & 5.928039 \\
\hline Median & 0.043432 & 0.075929 & 0.7 & 0.039933 & 1.379433 & 4.230806 & 5.852124 \\
\hline SD & 0.145378 & 0.129186 & 0.21427 & 0.091067 & 0.759259 & 0.965916 & 0.633578 \\
\hline Variance & 0.021135 & 0.016689 & 0.045912 & 0.008293 & 0.576474 & 0.932994 & 0.401421 \\
\hline Skewness & 0.327964 & 0.268644 & -0.96309 & 0.71578 & 2.465294 & -0.42281 & 0.776001 \\
\hline SE of & 0.107938 & 0.107938 & 0.108359 & 0.108359 & 0.107938 & 0.108148 & 0.107938 \\
\hline Kurtosis & 0.242809 & 2.104362 & 0.27838 & 2.490326 & 9.18956 & 1.38642 & 0.348412 \\
\hline SE of & 0.215461 & 0.215461 & 0.216299 & 0.216299 & 0.215461 & 0.215879 & 0.215461 \\
\hline Range of & 0.76275 & 1.074642 & 0.96 & 0.75559 & 5.766124 & 5.467127 & 3.1336 \\
\hline Min & -0.30663 & -0.55249 & 0 & -0.31176 & 0.58077 & 1.322219 & 4.732136 \\
\hline Max & 0.456116 & 0.522154 & 0.96 & 0.443831 & 6.346894 & 6.789346 & 7.865736 \\
\hline
\end{tabular}


According to the data in table 1 , all variables could be analyzed statistically according to relevant indices. Table 1 shows the features of research variables. The row 1 of the table shows that the number of data for some variables is equal to 512 and the row 2 shows the mean value of collected variable independently. For example, mean value of DA is equal to 0.048171. Row 3 shows SD and row 4 shows variance and distribution of variable based on mean value and variance of DA is equal to 0.021135. Rows 5 and 7 show kurtosis and skewness of data based on normal bell-shaped curve. Among the variables, the variable "growth" to 2.465294 has the highest rightward skewness and INTPEX and Growth and $\mathrm{FCF}^{*} \mathrm{MSO}$ have highest kurtosis.

In row 9, the variances of min and max referred in two next rows are mentioned under the title of range of variance. In this regard, $\mathrm{FCF}^{*} \mathrm{MSO}$ has shown the lowest range of variance. In two last rows, min and max level of observations relevant to the data are reported. Min and max levels of DA are respectively equal to -0.30663 and 0.456116 .

\section{MULTIVARIATE REGRESSION MODEL}

For purpose of analysis of correlation among several independent variables compared to dependent variable, the best way is using multivariate regression.

$$
D A_{i, t}=\beta_{\circ}+\beta_{1} F C F_{i, t}+\beta_{2} M S O_{i, t}+\beta_{3} F C F \times M S O_{i, t}+\beta_{4} S I Z E+\beta_{5} I N T E X P_{i, t}+\varepsilon_{i t}
$$

Where; $\epsilon_{i, t}$ refers to random error and $\beta_{0}, \beta_{1}, \beta_{2}, \ldots \beta_{5}$ refers to model parameters showing respectively the slopes and intercepts. In table 2, results obtained from regression analysis are presented:

Table 2: Results of regression analysis

\begin{tabular}{|c|c|c|c|c|}
\hline Test & Number & F value & Sig & Result \\
\hline ANOVA & 512 & 3.059 & 0.006 & Fit model \\
\hline
\end{tabular}

Table 3 presents the results of ANOVA to evaluate the fitness of model and the probability or sig level of $\mathrm{F}$ is equal to 0.006 . The value is lower than 0.05 . Therefore, $\mathrm{H} 0$ is rejected at the confidence level of $95 \%$; meaning that there is a fit model at the confidence level of $95 \%$. 
Table 3: Results of ANOVA

\begin{tabular}{|c|c|c|c|c|}
\hline $\begin{array}{c}\text { Multivariate } \\
\text { regression }\end{array}$ & $\begin{array}{c}\text { Determinant } \\
\text { coefficient }\end{array}$ & $\begin{array}{c}\text { Adj. determinant } \\
\text { coefficient }\end{array}$ & S.E & Durbin-Watson \\
\hline 0.188 & 0.035 & 0.024 & 0.144028 & 1.354 \\
\hline
\end{tabular}

In table 3 , the determinant coefficient is obtained to 0.035 . It means that about $3.5 \%$ of variance in dependent variable is explained by independent variables. The value shows the intensity of correlation between variables. The value of Durbin-Watson test is not significantly different from 2 and is equal to 1.354 . The values close to 2 show lack of autocorrelation of residuals, which is another assumption of regression. In table 4 , the $\beta$ coefficient is estimated and the coefficients are tested using $\mathrm{t}$ statistics.

Table 4: $\beta$ Coefficient estimation

\begin{tabular}{|c|c|c|c|c|c|}
\hline \multirow{2}{*}{ Variables } & \multicolumn{2}{|c|}{ Non Std. coefficients } & \multirow{2}{*}{$\begin{array}{c}\text { Std. } \beta \\
\text { coefficients }\end{array}$} & Sig \\
\cline { 2 - 3 } & $\beta$ & SD & 0.3351 & -0.235 & 0.815 \\
\hline Constant & -0.017 & 0.072 & 0.358 & 2.579 & 0.010 \\
\hline FCF & 0.402 & 0.156 & 0.092 & 1.781 & 0.076 \\
\hline MSO & 0.063 & 0.035 & -0.381 & -2.672 & 0.008 \\
\hline FCF*MSO & -0.609 & 0.228 & 0.059 & 1.297 & 0.195 \\
\hline Growth & 0.011 & 0.009 & -0.123 & -2.625 & 0.009 \\
\hline INTEXP & -0.018 & 0.007 & 0.063 & 1.325 & 0.186 \\
\hline SIZE & 0.014 & 0.011 & & & \\
\hline
\end{tabular}

According to the data in table 4, for variables of FCF, FCF*MSO and INTEXP, sig level is lower than 0.05 and for the variable of MSO, it is lower than 0.1 . Therefore, as sig level of growth and SIZE is higher than 0.05, they are excluded from the model and the model is fitted again. Table 5 presents the estimation of $\beta$ coefficients with omission of Growth and SIZE variables. 
Table 5: Estimation of $\beta$ coefficients with omission of Growth and SIZE variables

\begin{tabular}{|c|c|c|c|c|c|}
\hline \multirow[t]{2}{*}{ Variables } & \multicolumn{2}{|c|}{ Non Std. coefficients } & \multirow{2}{*}{$\begin{array}{c}\text { Std. } \beta \\
\text { coefficients }\end{array}$} & \multirow[t]{2}{*}{$\mathrm{t}$} & \multirow[t]{2}{*}{ Sig } \\
\hline & $\beta$ & SD & & & \\
\hline Constant & 0.078 & 0.038 & & 2.025 & 0.043 \\
\hline FCF & 0.424 & 0.155 & 0.377 & 2.728 & 0.007 \\
\hline MSO & 0.063 & 0.035 & 0.093 & 1.798 & 0.073 \\
\hline $\mathrm{FCF}^{*} \mathrm{MSO}$ & -0.641 & 0.227 & -0.401 & -2.829 & 0.005 \\
\hline INTEXP & -0.017 & 0.007 & -0.110 & -2.490 & 0.013 \\
\hline
\end{tabular}

According to table 5, the model is presented as follows:

$$
D A_{i, t}=\beta_{\mathrm{e}}+0.377 F C F_{i, t}+0.093 \mathrm{MSO}_{i, t}-0.401 F C F \times \mathrm{MSO}_{i, t}-0.11 I N T E X P_{i, t}+\varepsilon_{u t}
$$

\section{MULTIVARIATE REGRESSION MODEL IN COMPANIES WITH LOW GROWTH}

To test hypothesis 2 , the regression model should be analyzed in companies with low companies.

$$
D A_{i, t}=\beta_{s}+\beta_{1} F C F_{i, t}+\beta_{2} M S O_{i, t}+\beta_{3} F C F \times M S O_{i, t}+\beta_{4} S I Z E+\beta_{5} I N T E X P_{t, t}+\varepsilon_{i t}
$$

Where; $\epsilon_{i, t}$ refers to random error and $\beta_{0}, \beta_{1}, \beta_{2}, \ldots \beta_{5}$ refers to model parameters showing respectively slopes and intercepts. In following tables, results of regression analysis in companies with low opportunity are presented.

Table 6: Results of regression analysis in companies with low opportunities

\begin{tabular}{|c|c|c|c|c|}
\hline Test & Number & F & Sig & Result \\
\hline ANOVA & 249 & 0.08 & 1.904 & Fitted model \\
\hline
\end{tabular}

Table 6 presents the results of ANOVA to evaluate model fitness. The sig level of $\mathrm{F}$ is equal to 0.08 . The value is lower than 0.1 . Therefore, $\mathrm{H} 0$ is rejected at the confidence level of $95 \%$; meaning that there is fit model at the confidence level of $95 \%$. 
Table 7: Results of ANOVA

\begin{tabular}{|c|c|c|c|c|}
\hline $\begin{array}{c}\text { Multivariate } \\
\text { regression }\end{array}$ & $\begin{array}{c}\text { Determinant } \\
\text { coefficient }\end{array}$ & $\begin{array}{c}\text { Adj. determinant } \\
\text { coefficient }\end{array}$ & $\begin{array}{c}\text { E.S } \\
\text { value }\end{array}$ \\
\hline 0.212 & 0.045 & 0.021 & 0.135634 & 1.46 \\
\hline
\end{tabular}

In table 7 , the determinant coefficient is equal to 0.054 ; meaning that about $4.5 \%$ of variances of dependent variable is explained by independent variables. The index shows the intensity of correlation between variables. Durbin-Watson value is not significantly different from 2 and is equal to 1.46. The values close to 2 show lack of autocorrelation of residuals as another assumption of regression.

In table 8 , estimation of $\beta$ coefficients is presented using partial t-test.

Table 8: $\beta$ Coefficient estimation

\begin{tabular}{|c|c|c|c|c|c|}
\hline \multirow{2}{*}{ Variables } & \multicolumn{2}{|c|}{ Non Std. coefficients } & \multirow{2}{*}{$\begin{array}{c}\text { Std. } \beta \\
\text { coefficients }\end{array}$} & Sig \\
\cline { 2 - 3 } & $\beta$ & SD & & -0.174 & 0.862 \\
\hline Constant & -0.018 & 0.101 & 0.408 & 1.805 & 0.072 \\
\hline FCF & 0.485 & 0.269 & 0.094 & 1.234 & 0.218 \\
\hline MSO & 0.0 .58 & 0.047 & -0.517 & -2.199 & 0.029 \\
\hline FCF*MSO & -0.840 & 0.382 & 0.024 & 0.384 & 0.701 \\
\hline Growth & 0.021 & 0.054 & -0.147 & -2.001 & 0.046 \\
\hline INTEXP & -0.021 & 0.010 & 0.079 & 1.077 & 0.283 \\
\hline SIZE & 0.015 & 0.014 & & & \\
\hline
\end{tabular}

According to the data in table 8, for variables of FCF*MSO and INTEXP, sig level is lower than 0.05 and for the variable of FCF, it is lower than 0.1 . Therefore, as sig level of Growth and SIZE is higher than 0.05 , they are excluded from the model.

\section{Multivariate regression analysis in companies with low growth and with free cash flows}

To test hypothesis 4 , it is required to analyze regression model in companies with low opportunity and free cash flows. 


$$
D A_{i, t}=\beta_{0}+\beta_{1} F C F_{i, t}+\beta_{2} M S O_{t, t}+\beta_{3} F C F \times M S O_{i, t}+\beta_{4} S I Z E+\beta_{5} I N T E X P_{i, t}+\varepsilon_{i t}
$$

Where; $\epsilon_{i, t}$ refers to random error and $\beta_{0}, \beta_{1}, \beta_{2}, \ldots \beta_{5}$ refers to model parameters showing respectively slopes and intercepts.

In table 9, results of regression analysis in companies with low opportunity and free cash flows are presented.

Table 9: Results of regression analysis in companies with low opportunity and free cash flows

\begin{tabular}{|c|c|c|c|c|}
\hline Test & Number & F & Sig & Result \\
\hline ANOVA & 126 & 1.061 & 0.390 & Not-fitted model \\
\hline
\end{tabular}

Table 9 presents the results of ANOVA to evaluate model fitness. The sig level of $\mathrm{F}$ is equal to 0.390 . The value is higher than 0.05 . Therefore, $\mathrm{H} 0$ is not rejected at the confidence level of $95 \%$; meaning that there is no fit model at the confidence level of $95 \%$. Hence, the rest of multivariate regression model is not followed. Therefore, in companies with low opportunities and free cash flows, there is no linear correlation.

The main objective of this study is to investigate the correlation of the effect of stock indices on the correlation between free cash flow and earnings management in companies listed on Tehran Stock Exchange. The results obtained from this study shows that in general, free cash flows of companies can be considered as a stimulant for earnings management and that the managers of companies with free cash flows and low growth most likely take measure for earnings management, so that they can provide some personal interests in short-term.

According to secondary hypothesis 2 , the results showed that there is no significant correlation between earnings management and stock indices in companies with high free cash flows and low growth opportunity and this shows that managerial stock ownership has been unable to prevent earnings management applied by managers in companies with free cash flows and low growth opportunity. 


\section{REFERENCES}

1. Tehrani, R. Hesarzadeh R, 2012, The Effect of Free Cash Flows and Restrictions on Financing on Over-Investment and Low Investment, Journal of Accounting Research, Year One, No. 3.

2. Saghafi, A. Porianasab, A. 2011, Theory of Earnings Management, Journal of Accounting Research, Second Year, No. 6.

3. Shahehang, R, 2013, Accounting Theory, Specialized Audit and Accounting Research Center of the Audit Organization.

4. Mashayekhi, B. and Safari M, 2011, Cash Flow from Operation and Earnings Management in Companies Listed on Tehran Stock Exchange, Journal of Accounting and Auditing, Faculty of Management, Tehran University, 2011 (Issue 44).

5. Mehrani, S. Bagheri B, 2012, Investigating the Effects of Free Cash Flows and Institutional Owners on Profit Management, Accounting Research, Number Two.

6. Noravesh, A., Ebrahimi Kerdar A, 2011, Investigation and explanation of the relationship of shareholders' composition with information symmetry and the usefulness of performance accounting criteria, Journal of Accounting and Auditing, Faculty of Management, University of Tehran, vol. 12, No. 42.

7. Henderson, A. And Michael van Breda, Trans: A Parsaeian, 2011, Accounting Theories, Terme Publications, Vol. I and II.

8. The Accounting Standards Board, 2011, Theoretical Foundations of Accounting and Financial Reporting in Iran, Audit Organization's Specialized Accounting and Auditing Research Center

9. Bebchuk, Lucian Arye and Jesse M. Fried. ,(2013), "Executive compensation as an agency problem". Journal of Economic Perspectives, 17, 3 ,(Summer).

10. Bebchuk, Lucian Arye and Jesse M. Fried. ,(2012), "Pay Without Performance: The Unfulfilled Promise of Executive Compensation". Boston: Harvard University Press.

11. Bebchuk, Lucian Arye and Oliver D. Hart. ,(2013), "Takeover bids vs. proxy fights in contests for corporate control". Harvard Law and Economics Discussion Paper No. 336 ,

12. Bebchuk, Lucian Arye, Jesse M. Fried, and David I. Walker. ,(2012), "Managerial power and rent extraction in the design of executive compensation". The University of Chicago Law Review, 69, 3 ,

13. Hart, Oliver. ,(2013), "Financial contracting". Journal of Economic Literature, 39. 
14. Jensen, M., and Meckling, W., (2013), "Theory of the firm: Managerial behavior, agency costs, and ownership structure". Journal of Financial Economics 3,(4): 305-60.

15. Jones, Jennifer J., (2014), "Earnings management during import relief investigations". Journal of Accounting Research, 29, 2, (autumn): 193-228.

16. Jordan, Charls E., and Stanley J. Clark., (2014), "The case of goodwill impairment under SFAS No. 142". Journal of applied business research, No. 2.

17. Koonce, L., and Mercer, M., (2005), "Using psychology theories in archival financial accounting research". Journal of Accounting Literature. 24.

18. MANZHEN FAN, ,(2014), "A STUDY OF FOREIGN EARNINGS MANAGEMENT USING AN EMPIRICAL DISTRIBUTION APPROACH", The University of Texas,

19. Petruska Karin A. ,(2013), "Accounting conservatism cost of capital, and fraudulent financial reporting. Kent State University Graduate School of Management". A dissertation submitted for the degree of Doctor of Philosophy.

20. Rajgopal, Shiva, Lakshmana Shivakumar, and Ana Simpson. ,(2007), "A catering theory of earnings management". London School of Economics. Working paper.

21. Ronen, Tavy and Varda Lewinstein Yaari. ,(2012), "On the tension between full revelation and earnings management: A reconsideration of the revelation principle". Journal of Accounting, Auditing and Finance, 17,4 ,(Fall): 273-294.

\section{How to cite this article:}

Joudaky A. Effect of stock indices on cash flow and earnings management. J. Fundam. Appl. Sci., 2017, 9(2S), 1221-1236. 